\title{
保存処理された合板・単板積層材の接着性能 Adhesive Properties of Plywood and Laminated Veneer Lumber Treated with Preservatives
}

\author{
宮 㠃 淳 子* \\ Junko MIYAZAKI
}

\section{1.はじめに}

合板, 単板積層材 (LVL) とは, 木材を切削して得ら れる厚さ数 $\mathrm{mm}$ の単板を積層接着した材料である。合板 は各単板を緎維方向が互いにほぼ直交するように積層した 面材料で, LVL は各単板を繊維方向がほぼ平行になるよ うに積層した軸材料である。いずれも家具, 内装材から構 造材まで幅広い用途に用いられている。最近は, 特に建築 物の構造材や下地材としての使用量が増加している。これ らの用途の一部については, 建築基準法施行令において 「構造耐力上主要な部分は, 地面から $1 \mathrm{~m}$ 以内に防腐・防 蟻処理を講じる」と規定され，フラット 35 の工事使用書 においては「土台の防腐・防蟻措置は，高耐久樹種または 防腐・防蟻処理材を用いる」と規定されており，保存処理 材を用いることが求められている。

合板, LVLへの一般的な保存処理方法は, 次の 3 つで ある。（1）通常の方法で合板，LVLを製造した後，木材 保存䬉を含浸させる方法（製板処理法）（2）単板に木材 保存阂を含浸した後に積層接着する方法 (単板処理法) （3）木材保存昘を接着凪に添加し，積層接着する方法（接 着剤混入法)。これらの保存処理は, 接着層への負荷, 接 着面および接着剤自体の改質を伴うことから，保存処理に よって合板, LVL の接着性能に及ぼす影響について十分 に検討しておく必要がある。こうした背景から, 著者らは 保存処理が合板, LVLの接着性能に及ぼす影響について 検討してきた。本稿では,これらの成果をまとめるととも に, 近年の保存処理合板・LVL の接着性能に関する研究

\footnotetext{
* (地独) 北海道立総合研究機構 林産試験場 旭川市西神楽 1 線 10 号 $\overline{\text { T 071-0198 }}$

Hokkaido Research Organization Forest Products Research Institute

1-10 Nishikagura, Asahikawa, Hokkaido 071-0198, Japan
}

報告を紹介し, 上述の 3 つの保存処理方法が合板 $\cdot$ LVL の接着性能に及ぼす影響について概説する。

\section{2. 製板処理による接着性能への影響}

製板処理とは，通常の方法で製造した合板・LVLに保 存処理を施す方法である。保存処理の方法としては, 塗布 や浸せき, 吹付け, 加圧注入などがあり, 一般的には加圧 注入処理が行われている。加圧注入処理は，薬液に製板を 浸せきし，減圧・加圧する方法である。材料の深部にまで 薬液を浸透させることができるため, 高い耐久性を付与で きるが, 減圧加圧処理の工程とその後の乾燥工程で, 木材 は膨潤収縮するため, 接着層に負荷がかかる可能性が考え られる。

スギ, メランチ単板をフェノール樹脂で積層接着した $3 \mathrm{ply}$ 構成, $9 \mathrm{~mm}$ 厚の合板に水溶性木材保存剂である $\mathrm{AAC}$ (第 4 級アンモニゥム化合物系), ACQ (銅・第 4 級アン モニウム化合物系), CUAZ (銅・アゾール系)，および油 溶性木材保存剤である AZN (アゾール・ニコチノイド化 合物系) を加圧注入した保存処理合板について, 合板の日 本農林規格 (JAS) に準じたスチーミング繰り返し試験, 72 時間連続煮沸試験を行い，接着性能を調べた結果，こ

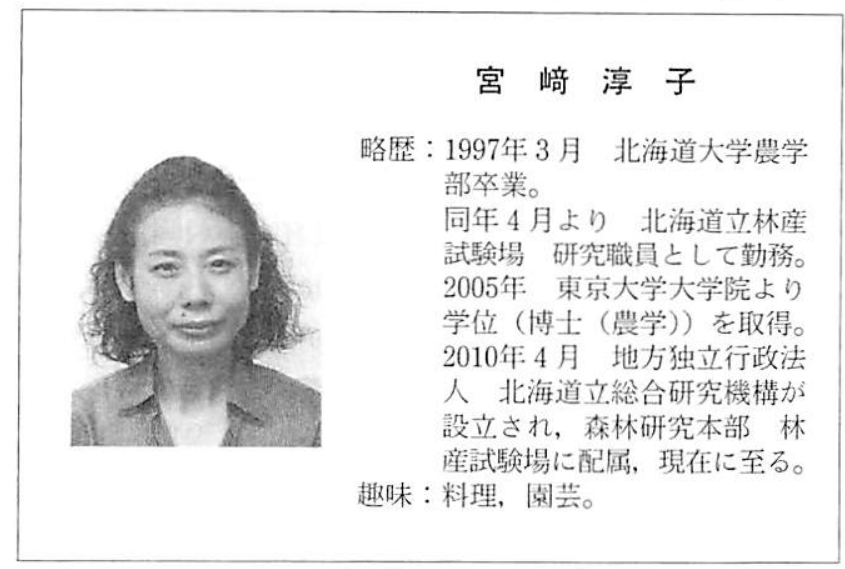


表 1 製板処理法を用いて製造された保存処理合板の常態接着強さ,スチーミング繰り返し試験 および連続煮沸試験後の接着強さ 1 3)

\begin{tabular}{|c|c|c|c|c|c|c|c|c|c|}
\hline & \multicolumn{3}{|c|}{ 常態試験※1 } & \multicolumn{3}{|c|}{ スチーミング繰り返し試験”2 } & \multicolumn{3}{|c|}{ 連続煮沸試験※3 } \\
\hline & 接着強さ & 標準偏差 & 木破率 & 接着強さ & 標準偏差 & 木破率 & 接着強さ & 標準偏差 & 木破率 \\
\hline & $\mathrm{N} / \mathrm{mm}^{2}$ & $\mathrm{~N} / \mathrm{mm}^{2}$ & $\%$ & $\mathrm{~N} / \mathrm{mm}^{2}$ & $\mathrm{~N} / \mathrm{mm}^{2}$ & $\%$ & $\mathrm{~N} / \mathrm{mm}^{2}$ & $\mathrm{~N} / \mathrm{mm}^{2}$ & $\%$ \\
\hline \multicolumn{10}{|l|}{ スギ } \\
\hline 無処理 & 1.21 & 0.28 & 82 & 0.87 & 0.26 & 86 & 0.80 & 0.26 & 68 \\
\hline ACQ & 1.07 & 0.35 & 88 & 0.80 & 0.24 & 75 & 0.80 & 0.25 & 42 \\
\hline AAC & 1.06 & 0.23 & 90 & 0.86 & 0.21 & 76 & 0.90 & 0.17 & 38 \\
\hline $\mathrm{CuAz}$ & 1.06 & 0.22 & 94 & 0.86 & 0.21 & 98 & 0.79 & 0.15 & 70 \\
\hline AZN & 1.07 & 0.24 & 91 & 0.83 & 0.21 & 98 & 0.91 & 0.18 & 68 \\
\hline \multicolumn{10}{|c|}{ メランチ } \\
\hline 無処理 & 1.33 & 0.29 & 90 & 1.09 & 0.30 & 100 & 1.08 & 0.37 & 100 \\
\hline ACQ & 1.13 & 0.29 & 86 & 1.04 & 0.31 & 100 & 1.05 & 0.32 & 58 \\
\hline AAC & 1.16 & 0.24 & 88 & 1.05 & 0.27 & 100 & 1.05 & 0.23 & 66 \\
\hline $\mathrm{CuAz}$ & 1.22 & 0.26 & 83 & 1.04 & 0.25 & 100 & 1.03 & 0.30 & 94 \\
\hline $\mathrm{AZN}$ & 1.23 & 0.27 & 90 & 1.01 & 0.29 & 100 & 1.01 & 0.34 & 88 \\
\hline
\end{tabular}

※1 クロスヘッドスピード $2,10 \mathrm{~mm} / \mathrm{min}$ で測定した接着強さの平均优。

$※ 2$ クロスヘッドスピード $10 \mathrm{~mm} / \mathrm{min}$

$※ 3$ クロスヘッドスピード $2 \mathrm{~mm} / \mathrm{min}$

れらの保存剤で処理された合板の接着強さは，基準值であ る $0.7 \mathrm{~N} / \mathrm{mm}^{2}$ を上回り, 無処理合板の接着強さと同等で あることが示された（表 1) 1 8)。一方，これらの保存処理 合板について，常態での引張りせん断接着試験を行った結 果, 保存処理合板の接着強さは, 無処理合板に比べてやや 低い傾向が認められた ${ }^{3)}$ 。このときの木部破断率は, 保存 処理合板と無処理合板でいずれも高い值を示したことから， 保存処理合板における接着強さの低下は, 薬剤の加圧注入 処理によって木材の強度が低下したためであると考えられ た。水溶性木材保存剤を用いた処理による木材の強度性能 への影響については, Winandy ${ }^{4)}$ が加圧注入処理によって 木材の MOR（曲げ強さ）が 0 ～20\%低下したと報告して いる。MOR の低下率の差異は保存剤の種類や吸収量, 加 圧注入後の再乾燥温度が関係している ${ }^{4 \sim 7)}$ 。

油溶性木材保存剂や油性木材保存剤を用いる処理では, 木材はあまり膨潤しないことから，接着層へのダメージは 小さいと考えられる ${ }^{8 \sim 10)}$ 。 Kimmel ら ${ }^{9)}$ は, フェノール樹 脂を用いて製造された LVLに油性木材保存剤であるクレ オソート油を加圧注入処理した場合, LVLの寸法变化は 厚さ方向で $2 \sim 6 \%$, 幅, 長さ方向では $1 \%$ 以下で, わず かであったことを報告している。これらの MOE（曲げャ ング係数), MOR, 平使いおよび縦使いのせん断強度は, 無処理の LVL とほぼ同等であった。
これらの報告から、フェノール樹脂を用いて製造された 合板・LVL は, 減圧加圧注入とその後の乾燥工程に耐え られる接着性能を有しており，製板処理によって接着強さ はほとんど損なわれないと言える。

\section{3. 単板処理が接着に及ぼす影響}

単板処理法とは，単板を浸せき処理や吹付け処理などに よって保存処理した後に積層接着する方法である。単板へ の保存処理方法としては, 水溶性木材保存剂を加圧注入す る方法が多く行われている。この方法で製造された合板, LVL は, 全層が保存処理されていることから, 高い耐久 性が期待できる。しかしながら，接着面になる単板表面は， 保存処理によって著しく改質されるため, 処理された単板 の接着性について十分に検討する必要がある。

著者ら ${ }^{3)}$ は，ACQ を用いた加圧注入処理による仮接着 性への影響を調べるために，単板にフェノール樹脂を塗布 した後, 30 分間泠圧し, 解放した後に室内環境下で平面 上に静置し，仮接着の状態の経時变化を観察した。無処理 では, 解放後, 60 分経過してもはく離しなかったが, ACQ 処理単板では, 5 分後に最外層の単板が反り返り, はく離 が観察された。このことから，ACQで処理された単板は， 仮接着が悪いことが示された。熱圧後の接着強さについて は, $\mathrm{ACQ}$ 処理合板では無処理合板の 5 割程度にまで低下 


\section{した。}

ACQ で処理された単板を接着した際に認められた仮接 着の悪化と熱圧後の接着強さの低下は, $\mathrm{ACQ}$ 処理によっ て単板のぬれ性が向上したことから，接着剤の過浸透が引 き起こされたことが一因であると考えられた ${ }^{3)}$ 。 ACQ の 他に, AAC, CUAZで処理した木材についてもぬれ性が 向上することが報告されており ${ }^{8)}$, これらの薬剤で保存処 理した単板を接着する場合には，過浸透を引き起こす可能 性があることを考慮すべきであると考えられる。他方, ホウ素化合物を浸せき処理した単板では, ぬ栍が悪化し た ${ }^{12)}$ 。ホウ素化合物で処理された単板をユリア樹脂で接 着し, 接着強さを調べた結果, 単板処理によって接着強さ は低下することが示された ${ }^{12)}$ 。

また, 加圧注入処理後, 乾燥された木材には, 割れや狂 い，木理に沿った凹凸が現れる ${ }^{13)}$ 。表面の平滑性が損なわ れることは, 接着性能の低下を引き起こすことが㦝念され る。ただし，ぬれ性の向上に伴う接着剤の過浸透や表面の 粗さが増すことによる接着不良は, 塗布量の増加や圧締圧 力の増加によって改善できる場合がある(14)。また, 樹種に よっては, 接着性能が低下しない場合むある3,8,13,14)。先 に紹介した著者ら ${ }^{3)}$ による $\mathrm{ACQ}$ 処理単板の接着性能の検 討では, メランチ単板を用いた場合, 接着剂の塗布量が $222 \mathrm{~g} / \mathrm{m}^{2}$ (片面あたり $20 \mathrm{~g} / 900 \mathrm{~cm}^{2}$ ) で無処理の 5 割程度 にまで低下したが，塗布量を $250 \mathrm{~g} / \mathrm{m}^{2}$ (片面あたり $22.5 \mathrm{~g}$ / $\left.900 \mathrm{~cm}^{2}\right)$ に増やすと接着強さは, 合板の JAS の基準を満 たす值にまで向上することが示された。また，スギ単板を 用いた場合, 溘布量が $222 \mathrm{~g} / \mathrm{m}^{2}$ でも ACQ 処理合板の接 着強さは無処理と同程度であることが示された。

木材保存剂の混入がフェノール樹脂の硬化反応に影響す

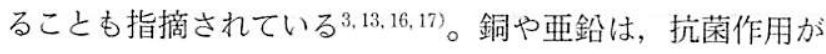
高く, 環境への負荷が比較的低いことから多くの木材保存 剤で使用されているが，これらをはじめとする多くの金属 塩は, フェノール樹脂の硬化反応に影響することが知られ ている ${ }^{18)}$ 。著者ら ${ }^{3)}$ は ACQ がフェノール樹脂の硬化に及 ぼす影響を調べるため, TBA (Torsional braid analysis)

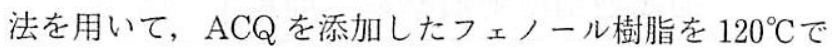
加熱した時の硬化過程の動的粘弾性の経時変化を調べた。 フェノール樹脂の硬化過程では, 時間の経過に伴い $G^{\prime} / G_{\infty}^{\prime}\left(G_{\infty}^{\prime}\right.$ 値は任意温度（ここでは $120^{\circ} \mathrm{C} ）$ で 60 分間加 熱した後に $180^{\circ} \mathrm{C} て ゙ 20$ 分間加熱した時の $G^{\prime}$ 值）は加熱時 間の経過とと屯に増大し, $\tan \delta$ は減少した後, 一定値に 到達した。 $G^{\prime} / G_{\infty}^{\prime}, \tan \delta$ が一定值に達した時点で力学的 な観点での硬化が完了したと考えられる。ACQの添加量 を $3 \% ， 5 \%$ としたときには， $G^{\prime} / G_{\infty}^{\prime}, \tan \delta$ が短時間で 一定值に到達し,フェノール樹脂の硬化が促進されたこと が示されたが, 添加量を $0.5 \%$ としたときは, ACQを添 加していないフェノール樹脂とほぼ同様の経時変化を示し,
硬化に影響しないことが示唆された。また，ホウ酸塩につ いてもフェノール樹脂のゲル化に影響する18)ことや, 接着

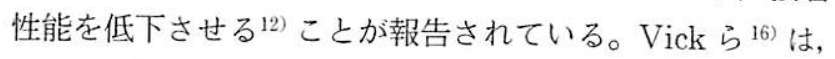
DDAC（ジデシルジメチルアンモニウムクロライド，第4 級アンモニウム化合物のひとつ), $\mathrm{DDAC}+$ 銅, DDAC+ カルバミン酸塩, ACB (Ammoniacal copper borate), ACZA，フッ化ナトリゥム，フッ化アンモニウムを加圧注 入処理した単板をつェノール樹脂で接着し, 接着強さを調 べた結果，ACB，ACZA を単板に加圧注入した場合に接 着強さと木部破断率が低下すること, 薬剤の吸収量を増や すと接着強さはさらに低下することを示した。

これらの結果から，金属塩やホウ酸塩などフェノール樹 脂の硬化反応に影響する化合物は，フェノール樹脂中に多 量に混入されないようにする必要があると考えられる。 Lorenz ら ${ }^{17)}$ は, 銅化合物は, 保存処理材から溶出しやす い場合に接着剤の硬化促進に関与すると述へている。保存 処理された木材を接着する際, 木材保存剤の成分が塗布さ れた接着剤中に溶出しないよう保存剤の成分を木材中に定 着させるには, 加圧注入処理の後に単板を十分に養生, 乾 燥させることが有効である ${ }^{4,19,20) 。}$

また，第 4 級アンモニウム化合物では，フェノールーレ ゾルシノール共縮合樹脂の硬化に影響しないことが報告さ れており ${ }^{11,17)}$, 有効成分の種類に配慮することす, 木材保 存剤によるフェノール樹脂の硬化に対する干渉を避けるた めには有効である。

これまでに紹介した報告を概観すると， ACQをはじめ とする水溶性木材保存剤を用いた単板処理では, 接着性能 に影響する複数の因子があるが, 良好な接着性能を得るこ とは可能であることが示されている。著者らのグループに よる検討の結果 ${ }^{1 \sim 3)}$, ACQ を用いた単板処理合板の接着 強さは，無処理合板よりも低下したものの，JAS 基準値 をクリアすることが示された（表 2)。また，荘保ら ${ }^{15}$ ) は, $\mathrm{ACQ}$ 処理単板を積層接着した合板について, スチーミン グ繰り返し試験, 連続煮沸試験を 5 サイクル行い, 各サイ クルでの接着強さを無処理合板のそれと比較した結果, 保 存処理合板の接着強さは, 無処理合板と同等であったこと を報告している。

他方, 乳化性木材保存剂や油溶性木材保存剤は, 水に不 溶な成分で構成されており,これらの保存剤を注入, 乾燥 した木材の細胞壁表面には極性の低い沈殿が堆積するため, フェノール樹脂と木材との接触が妨げられて接着強さが低 下する ${ }^{5)}$ 。Vick ら ${ }^{16)}$ は, 乳化性木材保存剂に界面活性剂 や水酸化アンモニゥムを添加し, 薬㓮成分の溶液中での安 定性を改善した結果, 接着強さが改善されたことを報告し ている。また, 界面活性剤等で改良された乳化ナフテン酸 銅を用いて保存処理された単板の接着性能を検討した結果, クローズドアッセンブリタイムを 10 分にした場合, 木部破 
表 2 単板処理法を用いて製造された保存処理合板の常態接着強さ，スチーミング繰り返し試験 および連続煮沸試験後の接着強さ1 33

\begin{tabular}{|c|c|c|c|c|c|c|c|c|c|}
\hline & \multicolumn{3}{|c|}{ 常態試験前1 } & \multicolumn{3}{|c|}{ スチーミング絽り返し試験※2 } & \multicolumn{3}{|c|}{ 連続募沸試験※3 } \\
\hline & 接着強さ & 標準偏差 & 木破率 & 接着強さ & 標準偏差 & 木破率 & 接着強さ & 標準偏差 & 木破率 \\
\hline & $\mathrm{N} / \mathrm{mm}^{2}$ & $\mathrm{~N} / \mathrm{mm}^{2}$ & $\%$ & $\mathrm{~N} / \mathrm{mm}^{2}$ & $\mathrm{~N} / \mathrm{mm}^{2}$ & $\%$ & $\mathrm{~N} / \mathrm{mm}^{2}$ & $\mathrm{~N} / \mathrm{mm}^{2}$ & $\%$ \\
\hline \multicolumn{10}{|l|}{ スギ } \\
\hline 無処理 & 1.21 & 0.28 & 82 & 0.87 & 0.26 & 86 & 0.80 & 0.26 & 68 \\
\hline ACQ & 1.04 & 0.30 & 89 & 0.72 & 0.16 & 83 & 0.80 & 0.20 & 73 \\
\hline \multicolumn{10}{|c|}{ メランチ } \\
\hline 無処理 & 1.33 & 0.29 & 90 & 1.09 & 0.30 & 100 & 1.08 & 0.37 & 100 \\
\hline ACQ & 1.02 & 0.22 & 93 & 0.85 & 0.18 & 100 & 0.86 & 0.21 & 68 \\
\hline
\end{tabular}

$※ 1$ クロスヘッドスピード $2,10 \mathrm{~mm} / \mathrm{min}$ で測定した接着強さの平均值。

$※ 2$ クロスヘッドスピード $10 \mathrm{~mm} / \mathrm{min}$

$※ 3$ クロスヘッドスピード $2 \mathrm{~mm} / \mathrm{min}$

断率は 30\%之低い值を示したが, 20 分に延長すると $80 \%$ に増加したことから，クローズドアッセンブリタイムを十 分に取り, 単板内部に接着剤を十分に浸透させることが必 要であると述べている211。ただし, 界面活性剤の種類によっ ては, 接着剤の過浸透を引き起こし, 接着不良が発生する ことも示されている211。

\section{4. 接着剤混入処理が接着に及ぼす影響}

接着剤混入法は, 接着剤に木材保存剤を混合するだけで, あとは通常の合板・LVL と同様に製造すればよいことか ら, 保存処理のために特別な装置を導入する必要がなく, 簡便で経済的にも有利な方法である。単板に塗布された糊 液中から有効成分が木材中に浸透し, 生物劣化に対する耐 久性が付与される。

接着剤混入法は, 乾材害虫であるヒラタキクイムシに対 する防虫性能を付与する方法として, すでに合板の JAS で 防虫合板として認定されている。そのため, この方法によっ て合板への木材腐朽菌に対する耐性を付与することも可能 ではないかと期待されたが, ある程度の耐朽性能を付与す ることは可能であったものの, 加圧注入処理之同等の耐朽 性能を付与することは困難であったと報告されている22,23)。 伏木 ${ }^{24)}$ は, 有効成分の多くが接着層の内部に留まってお り，腐朽菌の発生を抑制するには保存処理剤を多量に混入 する必要があると述べている。しかしながら，近年では， 薬剤の種類, 単板厚さを考虑す机ば, 接着剤混入法でも十 分な耐朽性能を付与できることが報告されている3,25 33)。

西本 ${ }^{25)}$ は，様々な薬剤を用いて接着剤混入法で保存処 理合板を製造し, 常態および連続煮沸後の接着強さを調べ た結果, TBP (トリブロモフェノール)や やIT-510 (N-4
ーメチルフェニルマレイミド）を用いて製造した保存処理 合板の接着強さは無処理合板の 50～60\%まで低下したが， IF-1000 (有機ヨード系薬剤)を混合した場合には無処理 合板の接着強さとほぼ同程度であったことを報告している。 勝沢ら ${ }^{26)}$ は $\mathrm{N} ・ \mathrm{AZ}$ (イミダクロプリド・シプロコナソー ル製剤）抢よび $\mathrm{AC} \cdot \mathrm{AZ}$ （アセタミプリド・シプロコナ ゾール製剤）を用いて接着剤混入法で製造した LVLにつ いて, 構造用単板積層材の JAS に規定される接着強さの 基準を満たしたこと，同薬剤を用いて製造した合板につい て, スチーミング繰り返し処理後の接着強さは無処理材と ほぼ同程度であり，合板の JAS の基準をクリアしたこと を報告している。また，著者らのグループ 1 3) は, $\mathrm{CF} ・$ $\mathrm{IF} ・ \mathrm{IP}$ (シフェノトリン・IF-1000・IPBC), IM・IP・ $\mathrm{OPP}($ イミダクロプリド・IPBC・O-フェニルフェノール), $\mathrm{N} ・ \mathrm{AZ} ， \mathrm{AC} \cdot \mathrm{AZ}$ を用いて製造した構造用合板について 接着性能を調べた結果, 保存処理合板の接着強さは無処理 合板と同程度であり, 合板の JAS の基準を満たすことを 示している (表 3 )。

著者 ${ }^{3)}$ は, $\mathrm{CF} \cdot \mathrm{IF} \cdot \mathrm{IP}, \mathrm{IM} \cdot \mathrm{IP} \cdot \mathrm{OPP}, \mathrm{N} \cdot \mathrm{AZ}$, $\mathrm{AC} ・ \mathrm{AZ}$ がフェノール樹脂の硬化に及ぼす影響を調べる ため, TBA 法を用いて, 薬剤添加したフェノール樹脂を 等温加熱したときの硬化過程の動的粘弾性の経時变化を測 定した。その結果, $\mathrm{CF} \cdot \mathrm{IF} \cdot \mathrm{IP}, \mathrm{IM} \cdot \mathrm{IP} ・ \mathrm{OPP}, \mathrm{AC} \cdot$ $\mathrm{AZ}$ を添加した場合には硬化にほとんど影響しないことが 示されたが， N・AZ を添加した場合には硬化が遅延され ることが示された。そこで, $\mathrm{N} ・ \mathrm{AZ}$ を添加したフェノール 樹脂を用い，熱圧時間を变えて製造した合板について常態 での引張りせん断接着強さと合板 JAS に準じた連続煮沸 試験後の接着強さを調べた。なお供試した合板は, $3.2 \mathrm{~mm}$ 
表 3 接着剤混入法を用いて製造された保存処理合板の常態接着強さ，スチーミング繰り返し試験および 連続煮沸試験後の接着強さ 1 3)

\begin{tabular}{|c|c|c|c|c|c|c|c|c|c|}
\hline & \multicolumn{3}{|c|}{ 常態試験米1 } & \multicolumn{3}{|c|}{ スチーミング繰り返し試験※2 } & \multicolumn{3}{|c|}{ 連続募沸試験※33 } \\
\hline & 接着強さ & 標準偏差 & 木破率 & 接着強さ & 標準偏差 & 木破率 & 接着強さ & 標準偏差 & 木破率 \\
\hline & $\mathrm{N} / \mathrm{mm}^{2}$ & $\mathrm{~N} / \mathrm{mm}^{2}$ & $\%$ & $\mathrm{~N} / \mathrm{mm}^{2}$ & $\mathrm{~N} / \mathrm{mm}^{2}$ & $\%$ & $\mathrm{~N} / \mathrm{mm}^{2}$ & $\mathrm{~N} / \mathrm{mm}^{2}$ & $\%$ \\
\hline \multicolumn{10}{|l|}{ スキ } \\
\hline 無処理 & 1.25 & 0.31 & 88 & 1.06 & 0.21 & 70 & 1.05 & 0.22 & 75 \\
\hline $\mathrm{IM} \cdot \mathrm{IP} \cdot \mathrm{OPP}$ & 1.24 & 0.34 & 88 & 1.02 & 0.22 & 88 & 0.92 & 0.23 & 79 \\
\hline $\mathrm{CF} \cdot \mathrm{IF} \cdot \mathrm{IP}$ & 1.21 & 0.49 & 87 & 0.99 & 0.24 & 70 & 1.04 & 0.22 & 63 \\
\hline $\mathrm{N} \cdot \mathrm{AZ}$ & 1.31 & 0.37 & 86 & 1.02 & 0.20 & 91 & 1.09 & 0.26 & 85 \\
\hline $\mathrm{AC} \cdot \mathrm{AZ}$ & 1.31 & 0.34 & 90 & 1.02 & 0.22 & 97 & 1.08 & 0.17 & 85 \\
\hline \multicolumn{10}{|l|}{ メランチ } \\
\hline 無処理 & 1.36 & 0.20 & 93 & 1.16 & 0.24 & 100 & 1.13 & 0.22 & 95 \\
\hline $\mathrm{IM} \cdot \mathrm{IP} \cdot \mathrm{OPP}$ & 1.37 & 0.21 & 93 & 1.22 & 0.21 & 100 & 1.20 & 0.21 & 81 \\
\hline $\mathrm{CF} \cdot \mathrm{IF} \cdot \mathrm{IP}$ & 1.36 & 0.32 & 93 & 1.16 & 0.29 & 100 & 1.21 & 0.30 & 97 \\
\hline$N \cdot A Z$ & 1.42 & 0.24 & 92 & 1.24 & 0.23 & 100 & 1.23 & 0.25 & 96 \\
\hline $\mathrm{AC} \cdot \mathrm{AZ}$ & 1.26 & 0.17 & 93 & 1.12 & 0.18 & 100 & 1.13 & 0.12 & 93 \\
\hline
\end{tabular}

※1 クロスヘッドスピード $2,10 \mathrm{~mm} / \mathrm{min}$ で測定した接着強さの平均值。

$※ 2$ クロスヘッドスピード $10 \mathrm{~mm} / \mathrm{min}$

$※ 3$ クロスヘッドスピード $2 \mathrm{~mm} / \mathrm{min}$

厚のメランチ単板を用いた 3 ply 構成のあのであった。そ の結果，木材保存剤を添加していないフェノール樹脂を用 いると熱圧時間が 282 秒 $(30$ 秒 $/ \mathrm{mm}$ ) で合板の JAS の 基準值をクリアする接着性能が得られたが, $\mathrm{N} ・ \mathrm{AZ}$ を混 合したフェノール樹脂で接着した場合には，基準值をクリ アするためには 329 秒 $(35$ 秒 $/ \mathrm{mm})$ 以上の熱圧時間が必 要であることが示された。

古田ら ${ }^{34)}$ は, 市販されている 2 種類の接着剤混入用木 材保存剂を用い, 種々の熱圧時間で製造した 10ply 構成, $30 \mathrm{~mm}$ 厚の LVL について, 構造用単板積層材の JAS に 準じた冷水浸せきはく離試験, 著沸はく離試験を行った結 果, 薬剤を添加したフェノール樹脂を用いてJASの基準 を満たす接着性能を得るには, 無処理 LVLょりも長い熱 圧時間が必要であることを示した。

著者ら ${ }^{35}$, 36) はこれらの木材保存剂を添加したフェノー ル樹脂について, $90 \sim 120^{\circ} \mathrm{C}$ で等温加熱した時の硬化過程 の動的粘弾測定 (DMA) 在行った結果, これらの木材保 存剤はフェノール樹脂の硬化を遅延することを示した。ま た，ここで用いた木材保存剤に含まれる防蟻・防腐成分で あるイミダクロプリド, シプロコナゾール, テブコナゾー ル,トリアジメホンはフェノール樹脂の硬化に影響しない が，溶㓮として含まれるベンジルアルコールはフェノール 樹脂の硬化を遅延することを明らかにした。さらにフェ
ノール樹脂の硬化はベンジルアルコールの添加量が多い方 がより遅延されることを示した。ベンジルアルコールは高 沸点である $\left(\mathrm{bp}=205^{\circ} \mathrm{C}\right)$ ことを考慮すると, 熱圧によっ てあ糊液から揮散しにくく, フェノール樹脂中に長く残存 し, フェノール樹脂の力学的な硬化の進展を遅延させたの ではないかと推測された。

また，加熱温度によってベンジルアルコールによる硬化 への影響は異なることが示された。120ㄷ゙加熱した場合, ベンジルアルコールを添加することによる硬化遅延はほと んど認められなかったが, 加熱温度を $100,90^{\circ} \mathrm{Cにすると}$ ベンジルアルコールを添加することによって顕著に硬化が 遅延されることが示された ${ }^{36)}$ 。LVL や厚物合板のように 厚い材料を熱圧する場合, 中央付近の接着層の温度上昇は 表層に比べてかなり緩やかである。古田らの報告 ${ }^{34)}$ では, $30 \mathrm{~mm}$ 厚, $10 \mathrm{ply}$ 構成の LVL を $130^{\circ} \mathrm{C}$ で熱圧した場合, 中央の接着層の温度は, 15 分後 $(30$ 秒 $/ \mathrm{mm})$ に約 $80^{\circ} \mathrm{C}$, 25 分後 $(50$ 秒 $/ \mathrm{mm})$ にようやく $100^{\circ} \mathrm{C} に$ 到達した。これ らの結果から, LVL や厚物合板など厚い材料に接着剤混 入法を適用する場合には, フェノール樹脂に対する硬化遅 延作用が顕著に表れる可能性が推察される。接着剤混入法 を用いて良好な接着性能を得るためには,これらの結果を 考慮し, 溶鼡の種類, 配合量, 熱圧条件を設定することが 重要であると考えられる。 


\section{5.おわりに}

保存処理が接着性能に及ぼす影響については, 合板, LVL をはじめ集成材や木質ボード類まで含めると，多く の研究が古くから行われてきており, 現在むなお続けられ ている。これまで, 薬剤の効力の向上や, 環境への配慮に よる使用禁止・自肃への対応のために, 次々と新しい薬㓮 の開発が進められ, その变遷に従って保存処理による接着 性能への影響が検討されてきた。今後も新たな薬剤が開発 され，保存処理技術は改良が進むことが期待される。本稿 が優れた防腐・防蟻性能，接着性能を兼权備えた木質材料 の開発にわずかながらでも貢献できれば幸いである。

\section{謝辞}

本報告の一部は, (独) 森林総合研究所交付金プロジェ クト（課題名「地域材を活用した保存処理合板の開発」 (H19-21))，およびに農林水産省 新たな農林水産政策 を推進する寒用技術開発事業（課題名「北海道産人工林材 を活用した低コストで高性能な単板集成材の開発と実用化」 (H22-24)）による成果をまとめたものである。共同で研 究に携わった方々，ご協力いただいた企業の方々に深く謝 意を表する。

\section{参 考 文 献}

1）井上明生, 宮本康太, 塔村真一郎, 平林靖, 古田直之, 宮㠃 淳子, 第 59 回日本木材学会大会研究発表要旨集, PN002 (CD-ROM) (2009).

2）平林靖，古田直之，宮崎淳子，秋津裕志，井上明生，第 59 回日本木材学会大会研究発表要旨集, PJ002 (2009).

3）宮㠃淳子, 平林靖, 古田直之, 井上明生, 塔村真一郎, 宮 本康太, “地域材を活用した保存処理合板の開発”, 森林総合 研究所交付金プロジェクト研究成果集，32，11（2011）.

4) J. E. Winandy, Proceendings of American Wood Preservers' Association, 91, 17 (1995).

5) J. E. Winandy, R. S. Boone, Wood Fiber Sci, 20, 350 (1988)

6) J. E. Winandy, R. S. Boone, L. R. Gjovik, P. L. Plantinga, Proc of the American Wood Preservers Assoc, 85, 106 (1989).

7) J. E. Winandy, S. T. Lebow, Forest Prod J, 47, 91 (1997).

8) D. J. Gardner, C. Tascioglu and M. E. P. Wålinder, "Wood Deterioration and Preservation, ACS Symposium Series Vol 845", ACS Publications, Washington DC, 399 (2003).
9) J.D. Kimmel, J.J. Janowiak, R.T. Baileys and P. Merrick, Forest Prod J, 44, 49, (1994).

10) F. A. Kamke and J. E. Winandy, Proc Annu Meet Am Wood Prot Assoc, 104, 116 (2008).

11）宮崎淳子, 中野隆人, 平林靖, 岸野正典, 木材学会誌, 45, 34 (1999).

12) I. Aydin and G. Colakoglu, Build Environ, 42, 3837 (2007).

13）宮㠃淳子, 中野隆人, 木材学会誌, 49, 212 (2003).

14）堀岡邦典, 林試研報, 89, 105 (1956).

15）荘保伸一, 新谷岳史, 山口秋生, 井上明生, 宮本康太, 第 26 回日本木材加工技術協会年次大会講演要旨集, 27 (2008).

16) C. B. Vick, R. C. De Groot and J. Youngquist, Forest Prod J, 40, 16 (1990).

17) L. F. Lorenz and C. Frihart, Forest Prod J, 56, 90 (2006).

18) A. Pizzi, "Wood adhesives. Chemistry and technology, Vol. 1." Marcel dekker, Inc., New York and Basel, 105 (1983).

19) B. Loubinoux, H. Malek, J. P. Joly and G. Kilbertus, Forest Prod J, 42, 55 (1992).

20) B.Loubinoux and H.Malek, Holzforschung, 46, 537 (1992).

21) C. B. Vick, Forest Prod J, 40, 25 (1990).

22) E. W. B. Da Costa, K. Hirst and L. D. Osborne, Holzforschung, 26, 131 (1972).

23）角田邦夫，木材保存，1985, 32 (1985).

24）伏木清行, 木材保存, 22, 22 (1996).

25）西本孝一，木材研究資料， 17, 60 (1983).

26）勝沢善永, 荒木五郎, 田中計実, 森岡健志, 第 22 回木質ボー ド・木質複合材料シンポジゥム 木材・プラスチック複合体 研究会 第 9 回公開講演集, 29 (2006)

27）高橋旨象, 角田邦夫, 今村祐嗣, 足立昭男, 西本孝一, 木材 保存, 11, 84 (1985).

28）佐藤俊夫, 真上真諭, 小田諭, 西本孝一, 木材保存, 11(1), 8 (1985)

29）中村嘉明, 坂野三傮子, 当麻毅, 中堀清, 佐藤俊夫, 奈良 県林試木材加工資料, 16, 4 (1987).

30）中村嘉明，奈良県林試木材加工資料， 14, 13 (1985).

31）中村嘉明，奈良県林試木材加工資料，14, 8 (1985).

32）斉藤光雄, 伊東英武, 土居修一, 布村昭夫, 林産試験場月 報, 320, 1 (1977)

33）善本知孝, 杉山慎吾, 木材学会誌，29, 815 (1983).

34）古田直之, 宮㠃淳子, 宮内輝久, 大橋義徳, 日本木材学会 北海道支部講演集, 43, 42 (2011).

http://www.agr.hokudai.ac.jp/wrsh/files/kouensyuu/ Volume43.pdf

35) J.Mliyazaki, N. Furuta and T. Miyauchi, J Apply Polym Sci, 印刷中.

36）宮㟝淳子, 古田直之, 宮内輝久, 大橋義徳, 日本木材学会 北海道支部講演集，43，26(2011).

http://www.agr.hokudai.ac.jp/wrsh/files/kouensyuu/ Volume43.pdf 